\title{
Effect of Motivation, Organizational Culture and Commitment on Employees' Performance: Department of Education and Culture of Papua
}

\author{
Fauziah F. Farawowan, Mugiati \\ Economic of College Port Numbay, Jayapura, Indonesia \\ University of Science and Technology, Jayapura, Indonesia \\ ff_farawowan@yahoo.com
}

\begin{abstract}
The purposes of this study were: 1). To examine and analyze the influence of Motivation, Organizational Culture and Employee Commitment to Employee Performance in the Office of Education and Culture of the province of Papua, and 2) to examine and analyze the factors that most dominant influence on Employee Performance Office of Education and Culture of the Province of Papua. Data collection methods used were observation, interviews and questionnaires. Data were analyzed descriptively and quantitatively using Multiple Linear Regression Analysis. The sampling technique using the technique of "Sample Saturated" The results showed that: Partial factor in motivation (X1), Cultural Organization (X2), and Employee Commitment (X3) significantly affects the Employee Performance Office of Education and Culture of the Province of Papua. Simultaneous and motivation factor (X1), Cultural Organization (X2), and Employee Commitment (X3) significantly affects the Employee Performance Office of Education and Culture of the Province of Papua. The most dominant variable influence on Employee Performance Office of Education and Culture of the province among the three variables above is the motivation factor.
\end{abstract}

Keyword: Motivation, Organizational Culture, EmployeeCommitment, employee performance

\section{Introduction}

Human resource development needs and strategic step for each local government. Substance important human resource development facing local autonomy and good governance is a paradigm shift, attitudes, values and behavior of the government apparatus. Therefore, there are several things to note, as barikut: 1) the need to restore or menginggatkan the mission and goals of bureaucracy / organization / public administration, so that what is done by bureaucrats or government officials right on target, 3) the demands of government officials which direform is government officials who are not related by control, order, prediction but rather lead to government officials who focus on alignment creativity and empowerment. Basically calls for a policy that is oriented to the principles of loose and tight, which is used as a political commitmen direction or guidance rather than political authority, and 4) government officials should be aware that they are public or civil servant whose job is to serve the public. Government organizations as public organizations present to organize and serve activities related to efforts to improve people's welfare. As an educational organization, aspects of the service becomes the main activity that employee satisfaction and community satisfaction as indicators of the organization's performance.

For that there are three (3) basic elements that underlie the regulation authority, among other things: 1) the activities that are routine for each organizational unit designated as official duties, 2) these tasks are relatively stable means no change -change means and authority to implement it fully bound by the rules that apply, and 3) there is no regularity in both the mechanisms and procedures, means that is standard to ensure the continuity of performance of duties by employees who qualify according conditions applicable provision.

Employee motivation is a condition or energy that drives self-employees are directed to achieve organizational goals (Mangkunagara, 2005: 61). The most important thing possessed by every employee who works for the organization of government are: 1) the mental attitude psychophysical (prepared mentally, physically, situation and goals), which means that the employee in performing the work are mentally prepared, physically healthy, understand the situation and conditions and strive to achieve employment targets as goals of the organization, 2) psychological aspect is very important in work motivation of employees to be able to work productively with full responsibility, among other things: a) employees should 
be encouraged to cooperate in the organization, b) employees always encouraged to work and tried in accordance with the demands of work, and c) an employee is able to maintain and develop human resources in the organization, and 3) the relationship between work motivation, work ability and cultural achievement in supporting the performance grouped into three categories, namely: 1) approach to the contents ( content theory), 2) a process approach (process theory), and 3) approaches amplifier (reinforcement theory).

Stephen (1996: 143), suggests that organizational culture is one factor that is important in influencing the performance of the company. This is because the organizational culture is an integral part of the internal environment of the organization. The cultural diversity that exists in an organization as numerous as the number of individuals in the organization. Culture can influence the behavior of members of the organization. Furthermore, Davis \& Newstrom (2000: 112), there are two (2) changes experienced by an individual, namely: 1) the transfer from one place to another with the culture of others, and 2) change slowly in the environment they are now. Employees need to learn to adjust to both of these situations to avoid negative consequences. If the organizational culture has touched fundamental in driving behavior and optimizes the ability of employees continuously in accordance with the objectives, then the organization's survival will last a long time.

\section{Literatur Riview}

Mangkunagara (2005: 73), the implementation of the theory of motivation at work can be divided into four sections, among other things: 1) intervention programs, the managerial skills that must be mastered by a leader. By understanding the important role of employee motivation will facilitate leaders expect achievement and job satisfaction of employees, 2) pay incentive plans, incentives granted to employees greatly affect the motivation, performance, and the performance of the employee, 3) job redesign, the process of influence in a sustainable manner and changes in work related to the characteristics of specific jobs expected to be more motivated employees, and 4) behavior modification, behavior modification related to work motivation with respect to: a) the value of the award is expected of employees, b) perception of employees in the attempt to achieve the award, c) business must be carried out, d) the ability and nature, e) the perception of the role, f) performance, g) award intinsik, h) the perception of a fair award, i) the level of job satisfaction is achieved by employees.

Hofstede, Hofstede and Minkov (2010: 165), the concept of culture has become mainstream in anthropology from the very beginning and gained attention in the early development of organizational behavior studies. However, only recently raised to the surface the concept of culture as a major dimension, understanding organizational behavior. Schein (1992: 78), suggests that a lot of work lately argued about the key role of organizational culture to achieve organizational excellence. Stephen (1996: 98), organizational culture as a common perception held by members of the organization ranggota and became a system of shared meaning. Meanwhile, Schein (1992: 145) chose a definition that can explain how culture develops, how it becomes a culture like this, or how culture can be changed if the organization's survival is at stake. It required a definition that can help understand the forces that influence the dynamic evolution of a culture to evolve and change. Employee commitment is the level of trust in accordance with the objectives of the organization and have a desire to remain in the organization (Robert \& Jackson, 2002). 


\section{Methodology}

Figure 1: Conceptual Framework

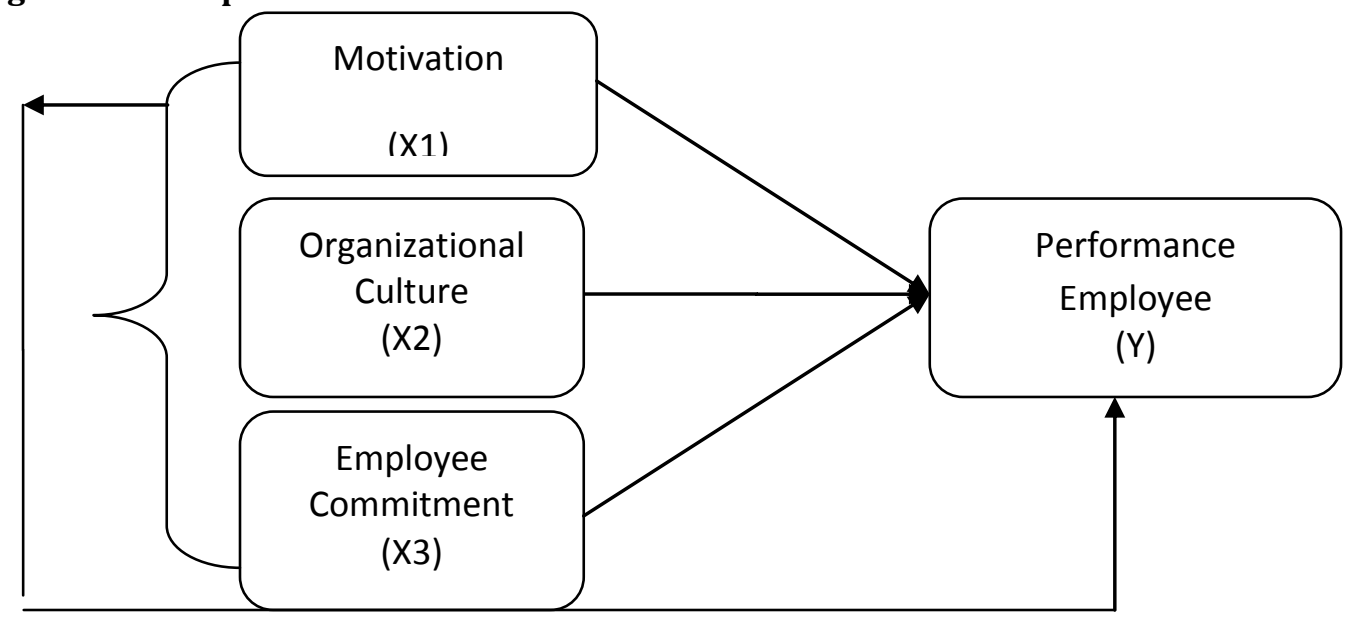

\section{Research Hypothesis}

- Factors of motivation, organizational culture and employee commitment partially significant effect on the performance of employees in the office of the Department of Education and culture of Papua Province.

- Factor motivation, organizational culture and commitment to employees simultaneously significant effect on the performance of employees in the office of the Department of Education and culture of Papua Province

Analysis Method: This study uses multiple regression analysis is used to determine the influence of independent variables on the dependent variable. Multiple regression analysis is as follows:

a. Multiple Regression Analysis .Because the research hypothesis formulated refers to the correlative study, the data analysis techniques using multiple regression statistical methods (multiple regression analysis). Data collected was processed using SPSS. While the model used in the analysis are:

$\mathrm{Y}=\mathrm{bo}+\mathrm{b} 1 \mathrm{x} 1+\mathrm{b} 2 \mathrm{X} 2+\mathrm{b} 3 \mathrm{X} 3+\mathrm{e}$

Where:

$\mathrm{Y}=$ Value Variable Bound (Performance)

bo $=$ Value $\mathrm{Y}$, if $\mathrm{X} 1$ and $\mathrm{X} 2=0$

$\mathrm{b} 1$ = amount Changes in the value of employee performance (Y) in units, if there is a change Motivation (X1) in one unit, while Cultural Organization (X2) and Employee Commitment (X3) Constant

b2 = magnitude Change in value of employee performance (Y) in units, if there is a change Cultural Organization (X2) in one unit, while the motivation (X1) and employee commitment (X3) Constant. b3 = amount performance value changes (Y) in units, if there is a change employee commitment (X3) in one unit, while the motivation (X1) and Cultural Organization (X2) Constant.

$\mathrm{e}=$ Standard Error

\section{Results}

In this study assumes that the motivation (X1), Cultural Organization (X2) and Commitment Employees (X3) on work performance $(\mathrm{Y})$ at the office of the Department of Education and culture of Papua Province assuming other variables are constant, it can seen in Table 1as follows: 
Tabel 1: Hasil Analisis Regresi Metode Enter

\begin{tabular}{lllll}
\hline Variabel Penelitian & $\begin{array}{l}\text { Regresi (Enter Method) } \\
\text { Koef. } \\
\text { Regresi } \\
(\boldsymbol{B})\end{array}$ & SE & $\mathbf{t}_{\text {hitung }}$ & $\begin{array}{l}\text { Sig. T } \\
(\boldsymbol{p})\end{array}$ \\
\hline Konstanta & 0,471 & 0,176 & 2,669 & 0,000 \\
Motivasi $\left(X_{1}\right)$ & 0,675 & 0,146 & 4,621 & 0,000 \\
Budaya Organisasi $\left(X_{2}\right)$ & 0,301 & 0,171 & 3,055 & 0,006 \\
Komitmen Pegawai $\left(X_{3}\right)$ & 0,267 & 0,150 & 2,783 & 0,009 \\
F ratio & & 153,209 & & 0,000 \\
Multiple R & & 0,939 & & \\
R Square & 0,881 & & \\
Adjusted R Square & & 0,875 & & \\
\hline
\end{tabular}

Keterangan: $\mathrm{F}_{\text {tabel }}(d f 3 ; 65=2,75(\alpha=0,05)$, two-tail test Sumber : Data Diolah, 2014

In Table 1, we can see the results of the regression analysis method showed that multiple regression coefficient (multiple R) obtained at 0.939 or $93.90 \%$, and $\mathrm{F}$ ratio of 153.209 at a significance level of $\mathrm{p}(0.000$ $<0.05$ ). Thus it can be said that all the independent variables, namely motivation (X1), Cultural Organization (X2), and Employee Commitment (X3) significantly and very strong to employee performance (Y) at the office of the Department of Education and Culture of the Province of Papua. Furthermore, the coefficient of determination (R2) obtained at 0.881 or $88.10 \%$ indicates the level of accuracy (goodness of fit) regression lines were established from the data of observation. This can be explained that the independent variable motivation (X1), Cultural Organization (X2), and employee commitment (X3) amounted to $88.10 \%$ and was not explained by $11.9 \%$ or $100-88.10 \%$. Variables that are not explained by $11,9 \%$ are the other variables that also affect employee performance variable (Y) beyond the motivation variable (X1), organizational culture (X2), and employee commitment (X3). This can happen because many factors can also affect employee performance beyond the three aforementioned factors or variables that have been studied were correct, it can be answered by conducting advanced research in connection with the performance of employees. However because researchers only limit on three variables are seen its influence on employee performance then the results can be expressed appropriate statistical test showed that. So it can be said that the variable of employee performance $(Y)$ influenced by other variables outside the model of $11.9 \%$.

\section{Conclusion and Recommendation}

- The issue of employee performance at the office of Education and Culture of the Province of Papua is an important issue, therefore the duties and functions of the office are particularly worth noting motivation, organizational culture and commitment to employees. Of the three factors that can be taken directly by the leadership policy is the motivating factor, it is necessary to note the increase in employee motivation and based on research motivating factor most dominant.

- To meet expectations as a Civil Servant (PNS) demands that can not be avoided, so that the pattern of service bureaucracy must be abandoned and replaced with the pattern of community service (customer focus) that puts people at the forefront as the basis of the presence of local government officials in organize and serve the public interest. It means that each employee to do the work that the results are good, it is worth noting three interactions employee motivation, namely: 1) the strength of themselves or their needs, 2) willing to succeed, and 3) the value of the incentives inherent in the goal.

- This research is very open to further research. It is therefore recommended to observers of the problems of motivation, organizational culture and commitment to employees, can conduct studies relating to the factors of what makes seseoarang or high performing employees. 


\section{References}

Davis, K. \& Newstrom, L. (2000). Behavior In Organization, seventh edition, the publisher, Jakarta

Hofstede, G., Hofstede, G. J. \& Minkov, M. (2010). Cultures and Organizations3rd edition. New York:Mc GrawHill.

Mangkunagara, A. P. (2005). Performance Evaluation of Human Resources. Publisher Refika Aditama Bandung. Miner, JB 1980. Theories of Organizational Behavior. Dryden Press, Hinsdale III.

Stephen, P. R. (1996). Organizational Behavior, Concepts, Controversies and Applications. Interpretation: Hadyana Pudjaatmaka. Sixth Edition. Publisher PT.Bhuana Popular Science, Jakarta.

Schein, E. H. (1992). Organizational Culture and Leadership, Jossey Bass, San Francisco.

Robert, L. M. \& Jackson, J. H. (2002). Human Resource Management; Book 2, interpreter Salemba Four. Jakarta. 